\title{
Millennials: America's cash cow is not necessarily a herd
}

\author{
Steven J. Migacz and James F. Petrick
}

Steven J. Migacz is a Doctora Candidate and an Instructor and James F. Petrick is a Full Professor and a Research Fellow, both at the Department of Recreation Park and Tourism Sciences, Texas A\&M University, College Station, Texas, USA
Received 4 December 2017 Accepted 13 December 2017 (C) Steven J. Migacz and James F. Petrick. Published by Emerald Publishing Limited.

This article is published under the Creative Commons Attribution (CC BY 4.0) licence. Anyone may reproduce, distribute, translate and create derivative works of this article (for both commercial and non-commercial purposes), subject to full attribution to the original publication and authors. The full terms of this licence may be seen at http://creativecommons. org/licences/by/4.0/legalcode

Funding was provided by the Monroe County Tourism Development Council $[\$ 16,000]$.

\begin{abstract}
Purpose - The purpose of this paper is to examine the travel motivations, perceived benefits of travel, and the utility of travel mediums among US millennials.

Design/methodology/approach - In order to further examine the homogeneity of millennial travelers, millennials were put into two subgroups based on their age and annual income. Data were collected in multiple phases, incorporating both qualitative and quantitative methodological approaches.

Findings - Results revealed that several significant differences exist between the proposed millennial subgroups, labeled "young and free millennials" and "professional millennials."

Research limitations/implications - Implications from this study include direction for both tourism marketers and destination suppliers based on the differences and perceptions of both groups and suggest millennials are not a homogeneous market.

Originality/value - Millennials are far from being part of a homogenous cohort. Therefore, the current study sought to examine differences in the benefits received from travel and the primary reasons to travel among distinct millennial segments.
\end{abstract}

Keywords Millennials, Professional millennials, Travel benefits, Travel motivations, Young and free millennials, Advertising mediums

Paper type Research paper

\section{Introduction}

Due to an increasingly competitive travel environment, today's tourists expect and demand diversity in both the settings and activities perceived to be inherent to a destination (Chung et al., 2015). Recognizing that destinations cannot be "everything to everyone," it is imperative for destination marketers to focus on specific markets. Thus, it is imperative for destinations to develop effective segmentation strategies.

Researchers and journalists have recently shown an increasing interest in and deference to the millennial generation (Garikapati et al., 2016; Zeng and Gerritsen, 2014). This perceived millennial influence or "power" is a result of two interrelated factors: purchase power and population size. With over 80 million "members," millennials make up more than a quarter of the population of the USA, which makes it the largest of the recognized generations (Fromm et al., 2015). Due to their growing impact on society, millennials could be suggested to be an excellent primary market for many destinations. However, according to Fromm and Garton, millennials are far from being part of a homogenous cohort. Therefore, the current study sought to examine differences in the benefits received from travel and the primary reasons to travel among distinct millennial segments.

\section{Literature review}

In addition to segmenting travelers via demographic factors, like age and income, tourism marketing researchers have also examined differences in travelers based on their motivations (Beh and Bruyere, 2007; Lu et al., 2015). Mayo and Jarvis (1981) explained that motivations are 
the driving force behind travelers' decision-making processes. For this reason, motivations have been suggested to be one of the most important variables for destinations/attractions to study (Crompton, 1979) and have led to a plethora of research in this area (i.e. Cha et al., 1995; Chen et al., 2014, Crompton, 1979; Dann, 1981; Iso-Ahola, 1982).

Regardless of the process in which these motivations become actualized, travel motivations have been found to play a critical role in tourists' decision making (Namkung and Jang, 2009) and destination selection (Yousefi and Marzuki, 2015). Much of the study of tourism motivations has revolved around the concept of "push" and "pull" factors. That is, individuals are first pushed by their own internal travel needs, and are then pulled to travel by external factors from travel destinations (Baloglu and Uysal, 1996). Push factors represent intangible or intrinsic desires of travelers. Conversely, pull factors are tangible, and emerge as a result of a traveler's perception of the attractiveness of a destinations (Baloglu and Uysal, 1996). This conceptualization is important, as understanding the main internal reasons why travelers decide to travel (push factors), can assist destinations in being much better equipped to develop amenities and packages that might appeal to them (pull factors).

While multiple motivations have been identified in the literature, Crompton (1979) suggested that seven socio-psychological, or push motives, prevail (escape, self-exploration/evaluation, relaxation, prestige, regression, enhancement of kinship relationships, and social interaction) and two cultural motives or pull motives prevail (novelty and education). Hence, multiple researchers have identified numerous other motivations for travel and have suggested that different generations are motivated differently (Lehto et al., 2008; Patterson et al., 2017).

\section{Travel benefits}

Travel motivations have also been found to be highly correlated with the perceived benefits of travel. While tourism researchers have routinely extolled the holistic benefits of travel with regard to overall life satisfaction (Petrick and Huether, 2013), other researchers have made attempts to quantify specific benefits of travel. Chen and Petrick (2013, p. 712) described tourism as "a tool for personal well-being, as a way to increase family and marriage satisfaction, and a way to seek knowledge." In addition, travel has been suggested to provide specific benefits to physical health, psychological and emotional wellness, as well as a remedy to stress related to work (Chen et al., 2014).

For tourism marketers, identifying key travel benefits (and promoting those that are appropriate with respect to the destination) can be critical to the success of a travel destination. For example, according to Crompton's (1979) choice set model, the destination choice is based on personal factors, destination attributes, and travel constraints. Thus, identification and effective communication of both push and pull factors (Patterson and Pan, 2007) and the benefits inherent to a particular destination (Chen and Petrick, 2013) can propel a travel destination to a preeminent position among the consideration set of destination choices.

According to Hsu and Kang (2009), customers are motivated to purchase products and services because of their inherent perceived benefits as opposed to their attributes. For example, tourists might travel to the Caribbean, not because of the sun and sand, but because the trip offers time to relax, have fun, and escape from the rigors of daily life. Subsequently, several tourism researchers have explored the potential perceived benefits of tourism, with some researchers reporting as many as 35 distinct travel benefits (Shoemaker, 1994).

Previous research has described travel benefits as being either utilitarian or hedonic in nature. For example, Chandon et al. (2000) identified both types of benefits in examining consumer behavior; quality, convenience, and savings (utilitarian benefits) and exploration and entertainment (hedonic benefits).

More recently, these benefits have been extended to include items, such as family bonding, memory making, stress reduction, and personal growth (Durko and Petrick, 2013; Chen and Petrick, 2013; Stone and Petrick, 2013). Thus, travel benefits have been found to be critical factors in the travel decision-making process, and identifying the specific benefits that target markets desire is likely important to destination management. 


\section{Millennials}

Segmenting travel types by age is common among tourism researchers (Pennington-Gray et al., 2003; Gardiner et al., 2012). Several have utilized the generational theory, as it proposes that travel behavior is determined by the effects of a shared environment and history (Pendergast, 2009). According to this theory, people who are born and grow up during a specific time period are distinctly different than other generational cohorts, thereby "influencing the cohort member's lifelong beliefs, values, attitudes, and behavior(s)" (Gardiner et al., 2012, p. 312).

Millennials, sometimes referred to as "Generation Y," are individuals born between 1979 and 1994 (Benckendorff et al., 2010). Millennials are thought to be responsible for nearly $\$ 200$ billion annually in expenditures (Beauchamp and Barnes, 2015), which has been suggested to be nearly half of all spending in the USA (D'Urso et al., 2016). In addition, it has been suggested that older generations are highly influenced by millennials with respect to consumer purchases, indirectly increasing millennial spending power to approximately $\$ 400$ billion annually (Muralidharan et al., 2016). Thus, millennials have been found to play a pivotal role as "advisor" and "influencer" to older generations with regard to their purchases of products and services (Fromm and Garton, 2013; Doster, 2013).

However, the appeal of millennials among destination marketers is not solely relegated to their impressive size and purchasing power. Previous studies have shown that millennials are considered to be highly educated and well traveled (prior to adulthood), particularly in comparison to other generations (Leask et al., 2014). According to Santos et al. (2016), millennials consider themselves explorers, and would rather spend money on experiences than materials things. In addition, it has been reported that 75 percent of millennials want to travel abroad as much as possible (Fromm and Garton, 2013), and take an average of 3.9 leisure trips and 4.2 business trips annually (Polzin et al., 2014).

The significant impact of millennials on tourism is recognized by many tourism researchers, yet generational analysis is not the only segmentation tool available to researchers (Collum and Daigle, 2015). More recently, researchers have acknowledged the need to further segment millennials, suggesting that additional segments exist (Hritz et al., 2014; Torres, 2015). Researchers have utilized several factors, including variables that encompass the "family life cycle" (Brida et al., 2013). For example, Garikapati et al. (2016) conducted a longitudinal analysis of the activity, travel, and time use patterns among millennials travelers. Their findings indicated significant differences among "younger millennials" (ages 18-24) and "older millennials" (ages 25-34). In addition, Garikapati et al. (2016) found that "older millennials" exhibited activity-time use patterns similar to "Generation X'erss."

However, most studies that have examined millennials have described them as a homogenous group. For example, Santos et al. (2016) suggested distinct travel profiles for millennials and senior groups, citing them as the two most important tourist segments. Although they suggested that the senior group was comprised of two subgroups ("younger at heart" and "older at heart"), no distinction was made among the millennials group.

While it is fairly obvious that people in their 20s look for different experiences than those in their 60s (Li et al., 2013), it is also possible that younger millennials with fewer resources are vastly different than older millennials with more resources. Thus, the current study utilized focus groups and follow-up panel studies to examine differences between millennial groups as it is believed the millennial generation provides tourism marketers with an attractive travel segment; one that has largely garnered interest among tourism researchers as a homogenous group.

\section{Millennials and information sources}

Due to the purchasing power and perceived influence that millennials hold in the market, it is imperative for destination marketers to develop strategies that help them to maximize their advertising efforts with optimal information sources (Loda et al., 2010). Characterized as being born "wired," it has been suggested that millennials place a great importance on sharing information and connecting with their social networks (Gurtner and Soyez, 2016). Although they have been found to spend the same amount of time online as non-millennials 
(Viswanatham, 2013), millennials have been found to be more likely to use social platforms such as Facebook, Twitter, Instagram, Yelp, and YouTube to broadcast their personal thoughts and experiences as a means to project their identities and gain validation (Fromm et al., 2015). In addition, it has been suggested that millennials largely receive their news from the internet (Chiang et al., 2014). Although social media clearly plays a significant role in the lives of millennials, little research on the use of social media among millennials exists (Bolton et al., 2013).

According to Belch and Belch (2015), millennials' disdain for traditional marketing approaches, combined with the high level of trust they place in the judgment of their peers (via word-of-mouth communication), suggests that traditional information sources might not be successful. Further, according to Kim et al. (2015), millennials use radio, travel documentaries, and movies to make travel plans, indicating that millennials seek a variety of information sources. Thus, the following research seeks to further investigate what types of information sources are most effective among millennials.

By segmenting millennials by age and income and understanding their motivations and benefits received, the results of this study should prove useful to tourism marketers tasked with developing activities designed for millennial travelers. With respect to promotional activities, results of this study should also provide a more accurate reflection of inter-generational motives and benefits, furnishing tourism marketers with more effective messaging strategies. Finally, by incorporating a qualitative methodology, it is believed that this paper could advance the knowledge of millennial travel motives and their perceived benefits of travel.

\section{Methods}

The current study was part of a larger project that was conducted to gain understanding of the travel behaviors of millennial travelers. Central to this study were objectives related to understanding the motivations, benefits, and marketing mediums used, related to millennial travel. In order to gain an initial understanding of the motivations, benefits, and mediums used, focus groups with 20 students from each of the following four universities in the USA were conducted: Texas A\&M University, the University of North Carolina-Wilmington, the University of Illinois, and California State University in Chico. These four universities were chosen as they represent vastly different geographic regions of the USA. The selection process was an attempt to further control any bias related to one geographic area. The resultant data were coded and put into themes by two of the researchers.

These coded themes identified that health, relationship, entertainment, and educative benefits were common, while other benefits were much less common. Thus, for the overall study (follow-up panel studies), these four benefits were measured on a five-point Likert-type scale with 1 "not at all beneficial," 2 "slightly beneficial," 3, "somewhat beneficial," 4 "very beneficial," and 5 "extremely beneficial." Respondents were also asked a follow-up open-ended question which stated, "What other benefits do you receive when traveling." These benefits were subsequently placed into themes by two researchers.

The initial step of categorizing perceived additional travel benefits required the two researchers to examine the two pools of responses independently and sort them into categories. The forming and subsequent labeling of additional travel benefit categories were grounded in considerations regarding validity and their practical use, as suggested by Butterfield et al. (2005). For example, the travel motivation category "Escape/Memory" was formed based on the practical necessity of retaining an adequate sample size as well as an acknowledgment that the responses initially coded to the category "Memory" were strongly associated with a desire to escape reality. Hence, the responses were meticulously examined by both researchers, resulting in a determination of appropriate labels for each theme.

After multiple iterations were completed to categorize the responses, a consensus was established between the two researchers. The two researchers agreed on a final tally of 13 categories representing additional travel benefits.

A third researcher with extensive experience in qualitative data was given the proposed theme labels and tasked to assign each of the responses to the theme considered most fitting. Of the 
1,111 motivation responses, all but 28 were categorized the same by the third researcher, resulting in 97.5 percent inter-judgement agreement. According to Swanson and Hsu (2009), the recorded inter-judgement agreement percentage exceeds the agreement level necessary to ensure the validity and reliability of the classification results.

Since primary motivations were not clearly defined from the initial focus groups, they were similarly asked with an open-ended question that asked, "What is the primary reason you travel." These results were also placed into themes by two researchers using the process as the one previously described and resulted in 11 motivation themes. Of the 1,111 additional travel benefit responses, 1,087 were classified correctly by the third researcher (97.8 percent). The inter-judge agreement for additional travel benefits was also deemed valid and reliable (Andersson and Nilsson, 1964).

The focus groups also revealed that the following mediums were used in travel planning by millennials: magazine ads, magazine articles, Facebook, newspaper ads, television ads, Twitter, TV shows/news stories, radio ads, Pinterest, YouTube channels, travel guides/books, web banners/internet ads, Tumblr, Trip Advisor, friends/family, Instagram, apps, Snapchat, Google, travel agent, destination websites, and online reviews. For the follow-up panel studies, respondents were asked how useful each medium was to them when making travel plans, with responses placed on a five-point Likert-type scale with 1 "not at all useful," 2 "slightly useful," 3 "moderately useful," 4 "very useful," and 5 "extremely useful."

Results of the initial focus groups also suggested that there were vast differences between younger millennials, and those that were both older and had better monetary resources. Thus, it was decided that the follow-up panel studies would split millennials into two groups based on their age, and to have the older segment require a minimum annual salary of over $\$ 100,000$ to reflect these vast differences. These two groups were termed "young and free millennials" ("YFMs") and "professional millennials" ("PMs"). Based on these results, separate online panel surveys were conducted for both millennial types, utilizing criterion sampling in the top 12 feeder states to the destination funding the research.

Panel studies were chosen as past research has shown them to be both valid and reliable as well as appropriate for similar studies (Ansolabehere and Schaffner, 2014; Hung and Petrick, 2012). While panel studies have been suggested to have potential for bias related to coverage as many people do not have internet coverage (Bosnjak et al., 2013), it was assumed that the vast majority of traveling millennials destinations would target to likely have internet access. Based on the focus groups results, the criterion used to select the samples included: those aged 18-24 for "young and free millennials" and those aged 25-25 with household incomes of \$100,000 or more for "professional millennials."

This process resulted in a total of 1,269 responses being collected, with 159 surveys being removed due to inconsistencies with respondent qualifications (i.e. income not high enough to be considered a "young and free millennials"). Thus, 1,111 valid and usable responses were collected from this process including 602 "young and free millennials" and 509 "professional millennials." Thus, the error rate associated with both samples was under 5 percent.

\section{Results}

\section{Classification of travel motivations}

The categorization process resulted in 11 themes related to primary travel motivations among millennials: hedonic interests, visiting friends and family, escape/memories, education/ sightseeing, rest/relaxation, novelty/adventure, business/status, leisure/recreation, selfexploration/evaluation, escape, NA and None. Each person who identified a travel motivation was coded as a member of the group related to their response (e.g. all persons who reported education/sightseeing were coded as 5).

For "young and free millennials," the travel motivations most often mentioned by respondents (with sample sizes of 50 or over) included: hedonic interests, visiting friends and family, NA, and escape/memories. For "professional millennials," the motivations most often mentioned by 
respondents included: hedonic interests, rest/relaxation, visiting friends and family, and escape/ memories. Examples of responses for each of the 11 travel motivation themes among "young and free millennials" and "professional millennials" are displayed in Tables I and II.

\section{Travel motivation differences among millennial groups}

Results of a Pearson's $\chi^{2}$ test indicated significant differences among "young and free millennials" and "professional millennials" ( $\chi^{2}=44.950, p<0.001$, Cramer's $\left.V=0.201\right)$. The examination of the cross-tabulation of the combined variables indicated that the travel motivations of "young and free millennials" were quite divergent to the travel motivations of "professional millennials" (Figure 1). Of all of the respondents who stated self-exploration and evaluation as a primary motivation to travel, 65.2 percent were "YFMs" and only 34.8 percent were "PMs." Similar discrepancies were found among all of the respondents who stated hedonic interests as a primary motivation to travel, as 62.6 percent were "YFMs" and only 37.4 percent were "PMs." Among all respondents to confirm education and sightseeing as a primary motivation to travel, 57.9 percent of them were "YFMs," yet only 42.1 percent of them were "PMs." Of all of the respondents who confirmed novelty and adventure as a primary motivation to travel, 57.5 percent were "YFMs" and only 42.5 percent were "PMs." Further, among all respondents to state family and friends as a primary motivation to travel, 55.2 percent were "YFMs" and just 44.8 percent were "PMs." It should also be noted that despite the small sample size $(n=16)$ of all of the respondents to find no primary motivation to travel, 87.5 percent of them were "YFMs," and only 12.5 percent of them were "PMs."

In contrast, "professional millennials" were found to state relaxation/rest, leisure and recreation, and business/status as the primary motivation to travel with greater frequency among all

Table I Travel motivations of "young and free millennials"

\begin{tabular}{lrrl} 
Category & $n$ & Percentage (\%) & Examples \\
\hline Hedonic interests & 214 & 35.5 & For fun; to enjoy life \\
Visiting friends and family & 74 & 12.3 & To see family; spend time with significant other \\
NA & 54 & 9.0 & Do not know; I do not travel \\
Escape/memories & 50 & 8.3 & To get away; to make memories \\
Education/sightseeing & 44 & 7.3 & Expand my horizons; to see the world \\
Rest/relaxation & 43 & 7.1 & Take a rest; to relax and unwind \\
Novelty/adventure & 42 & 7.0 & Do something new; adventure \\
Business/status & 26 & 4.3 & To attend conventions; networking \\
Leisure/recreation & 26 & 4.3 & Leisure; recreation \\
Self-exploration/evaluation & 15 & 2.5 & To find myself; to learn new things about myself \\
None & 14 & 2.3 & None; nothing \\
Total & 602 & 100 &
\end{tabular}

Table II Travel motivations of "professional millennials"

\begin{tabular}{lrrl}
\hline Category & $n$ & Percentage (\%) & Examples \\
\hline Hedonic interests & 128 & 37.4 & For fun; to enjoy life \\
Rest/relaxation & 82 & 16.1 & To see family; spend time with significant other \\
Visiting friends and family & 60 & 11.8 & Do not know; I do not travel \\
Escape/memories & 54 & 10.6 & To get away; to make memories \\
NA & 46 & 9.0 & Expand my horizons; to see the world \\
Leisure/recreation & 34 & 6.7 & Take a rest; to relax and unwind \\
Business/status & 32 & 6.3 & Do something new; adventure \\
Education/sightseeing & 32 & 6.3 & To attend conventions; networking \\
Novelty/adventure & 31 & 6.1 & Leisure; recreation \\
Self-exploration/evaluation & 8 & 1.6 & To find myself; to learn new things about myself \\
None & 2 & 0.4 & None; nothing \\
Total & 509 & 100 &
\end{tabular}




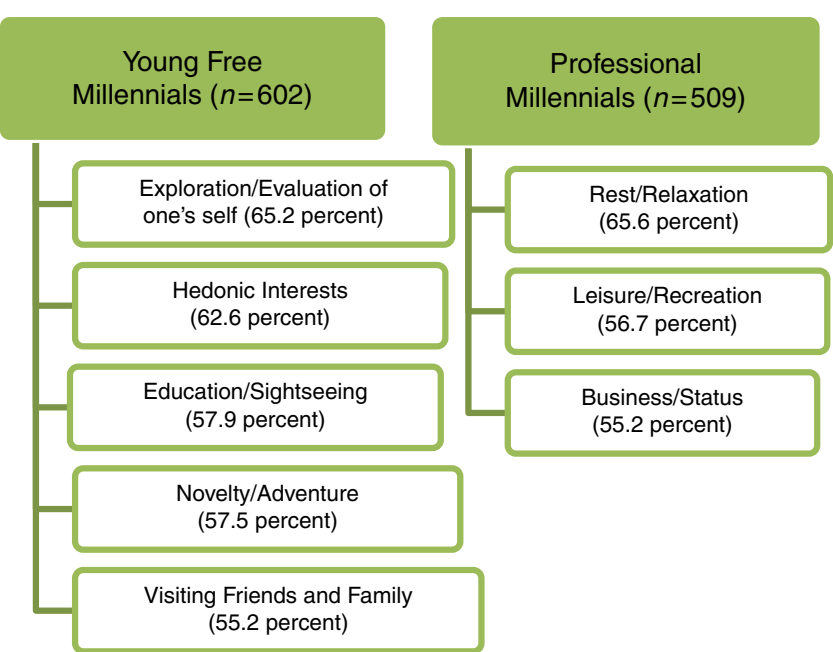

respondents. Among all respondents to list relaxation/rest as a primary motivation to travel, 65.6 percent were "PMs and 34.4 percent were "YFMs." Among all respondents to identify leisure and recreation as a primary motivation to travel, 56.7 percent were "PMs" and 43.3 percent were "YFMs." And, among all respondents to state business/status, 55.2 percent were "PMs" and 44.8 percent were "YFMs."

\section{Perceived benefits of travel}

As previously stated, the primary benefits of travel were identified as "Education," "Entertainment," "Relationships," and "Heath." Since these were known benefits, they were analyzed quantitatively. Independent $t$-tests were performed to examine differences of perceived importance of these benefits among "young and free millennials" and "professional millennials." Statistical differences were found among the two millennial groups for "Entertainment" $(t=3.871, p<0.0001)$, "Relationships" ( $t=9.110, p<0.0001)$, "Health" $(t=8.773, p<0.0001)$, and "Education" $(t=5.709, p<0.0001)$. Table III reveals the mean differences. It was also found that "young and free millennials" and "professional millennials" ranked all four travel benefits in the same order of importance: "Entertainment," followed by "Relationships," "Health," and "Education." It should be noted that "PMs" rated all four travel benefits significantly higher (see Table III).

\section{Classification of additional travel benefits}

The categorization process utilized to examine additional travel benefits resulted in the following 11 categories: relaxation/leisure, novelty, experience/memory, happiness/joy, education, relationships, health (mental and physical), entertainment/fun, extrinsic rewards, none, and NA.

\section{Table III Perceived benefits of travel}

Young and free millennials $(n=602)$

Professional millennial $(n=509)$

\begin{tabular}{llr}
\hline Travel benefits & Mean & Mean \\
Entertainment & $3.88^{*}$ & $4.12^{*}$ \\
Relationships & $3.51^{*}$ & $4.10^{*}$ \\
Health & $3.17^{*}$ & $3.78^{*}$ \\
Education & $3.12^{*}$ & $3.54^{*}$
\end{tabular}

Note: *Means are statistically $(p<0.001)$ different 
By sheer volume, the additional benefits of travel most often mentioned by "young and free millennials" were relaxation/leisure, novelty, none, and NA. Relaxation/Leisure, None and NA were the most frequent responses among professional millennials. Comprehensive lists of responses for each of the 11 additional benefit themes among "young and free millennials" and "professional millennials" are displayed in Tables IV and V.

\section{Additional travel benefit differences among millennial groups}

A Pearson's $\chi^{2}$ test was performed in order to examine significant differences among "young and free millennials" and "professional millennials" and their benefits received when traveling. Results indicated that the two millennial groups were significantly different in the benefits they receive from travel $\left(\chi^{2}=33.607, p<0.001\right.$; Cramer's $\left.V=0.174\right)$. Similar to results of the cross-tabulation utilized to examine primary motivations to travel, large differences between "young and free millennials" and "professional millennials" were identified. Among all respondents who cited experience/memory as an additional benefit of travel, 72.6 percent of them were YFMs, and only 27.4 percent of them were "PMs." Among all respondents to confirm novelty as a travel benefit, 63.7 percent of them were "YFMs," with only 36.3 percent of them being "PMs." Of all of the respondents who stated entertainment/fun as an additional benefit of travel, 60.4 percent were "YFMs" and 39.6 percent were "PMs." Further, of all respondents who claimed no additional travel benefits, 59.5 percent of them were "YFMs" and just 40.5 percent were "PMs." In addition, of all respondents to cite relationships as an additional travel benefit, 55.2 percent of them were "YFMs" and 44.8 percent of them were "PMs"

While "young and free millennials" represented the majority among all respondents for six additional benefits of travel, "professional millennials" represented a majority for only two. Of all of

\section{Table IV Additional perceived benefits of travel of "young and free millennials"}

\begin{tabular}{lrrl} 
Category & $n$ & Percentage (\%) & Examples \\
\hline None & 110 & 18.3 & None; I do not like to travel \\
Relaxation/leisure & 96 & 15.9 & Being able to relax; decompress \\
NA & 83 & 13.8 & Don't know; not sure \\
Novelty & 51 & 8.5 & Exposure to new experiences, new interesting food \\
Experience/memory & 45 & 7.5 & Life experiences; forever-lasting memories \\
Happiness/joy & 41 & 6.8 & I get to enjoy myself; happiness \\
Education & 39 & 6.5 & Understanding other cultures; knowledge \\
Relationships & 37 & 6.1 & Bonding with partner; quality time with family \\
Health (mental and physical) & 37 & 6.1 & Inner peace; exercise \\
Entertainment/fun & 32 & 5.3 & Fun; fun and amusement \\
Extrinsic rewards & 31 & 5.1 & Reward points; stamps on passport \\
Total & 602 & 100 &
\end{tabular}

Table V Additional perceived benefits of travel of "professional millennials"

\begin{tabular}{lrrl} 
Category & $n$ & Percentage (\%) & Examples \\
\hline Relaxation/leisure & 134 & 26.3 & Being able to relax; decompress \\
None & 75 & 14.7 & None; I do not like to travel \\
NA & 71 & 13.9 & Do not know; not sure \\
Health (mental and physical) & 46 & 9.0 & Inner peace; exercise \\
Education & 44 & 6.3 & Understanding other cultures; knowledge \\
Relationships & 30 & 5.9 & Bonding with partner; quality time with family \\
Extrinsic rewards & 29 & 5.7 & Reward points; stamps on passport \\
Novelty & 29 & 5.7 & Exposure to new experiences, new interesting food \\
Happiness/joy & 25 & 4.9 & I get to enjoy myself; happiness \\
Entertainment/fun & 21 & 4.1 & Fun; fun and amusement \\
Experience/memory & 17 & 3.3 & Life experiences; forever-lasting memories \\
Total & 509 & 100 &
\end{tabular}


the respondents who stated relaxation as an additional benefit of travel, 58.3 percent were "PMs" and 41.7 percent were "YFMs." Finally, of all the respondents who provided health as an additional travel benefit, 55.4 percent of them were "PMs" and 44.6 percent of them were "YFMs." Results identifying the largest discrepancies are provided in Figure 2.

\section{Perceived utility of travel mediums}

"Young free millennials" and "professional millennials" rated "friend or family member," "website of a specific destination," "search for online reviews," and "Google" as the most helpful mediums with respect to travel. However, while "young and free millennials" rated "travel guide (travel book) as the fifth most useful," "professional millennials" instead ranked "trip advisor" as the fifth most useful travel medium.

Although "young and free millennials" and "professional millennials" shared four of the five least useful mediums used for travel, the order by rank for each group was different. "Young and free millennials" ranked the bottom five travel mediums accordingly: magazine ads (mean $=2.25)$, newspaper ads ( mean=2.33), Twitter (mean=2.33), Tumblr (mean=2.35), and radio add (mean=2.37). However, "professional millennials" ranked Tumblr (mean $=2.44)$, Snapchat $($ mean $=2.45$ ), newspaper ads (mean $=2.50$ ), radio ads (mean $=2.56$ ), and magazine ads (mean $=2.59$ ) as the least useful travel mediums (see Table VI). Finally, it should be noted that the mean score for every utility of travel medium measured higher for "PMs" in comparison with "YFMs." Of the 22 proposed mediums rated for their utility in planning a trip, 13 were found to be statistically significant (via independent samples $t$-tests). Mean scores and significant differences in the $t$-tests $(p<0.05)$ of utility for travel mediums among "young and free millennials" and "professional millennials" are displayed for all travel mediums for both YFMs and PMs in Table VI.

\section{Discussion and implications}

Travel destination marketers are motivated to attract and retain millennials as they represent a large portion of the world's population and wealth (Fromm and Garton, 2013). In addition, research suggests that millennials have tremendous influence among non-millennials with regards to consumer purchases (Santos et al., 2016) and are highly motivated to travel (Kim et al., 2015).

Figure 2 Additional benefits to travel differences among millennial groups

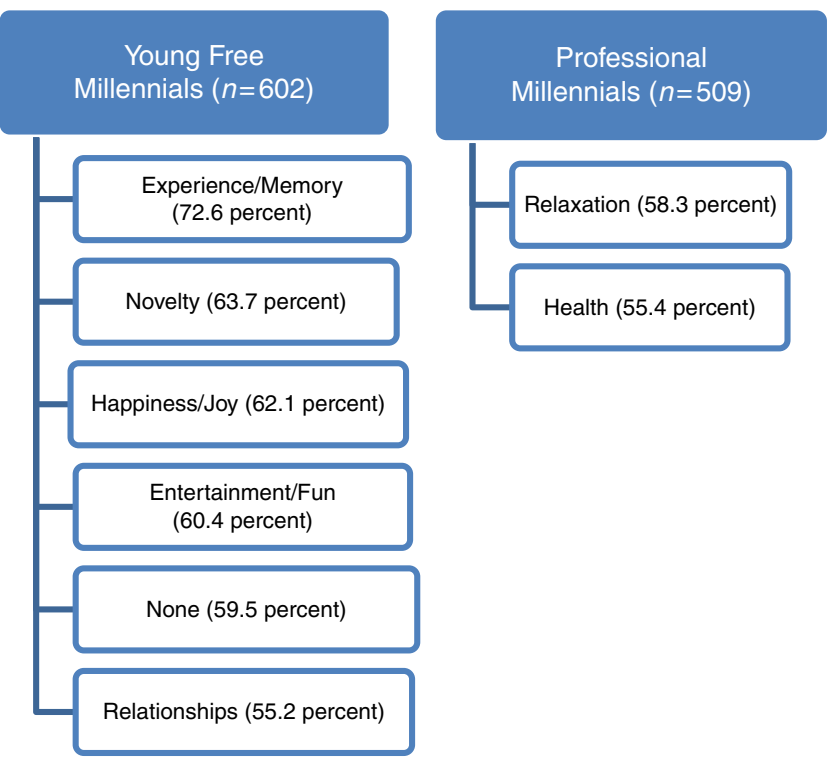


Table VI Travel medium utility

\begin{tabular}{lll} 
& $\begin{array}{c}\text { Young and free millennials } \\
\text { Mean }\end{array}$ & $\begin{array}{c}\text { Professional millennials } \\
\text { Mean }\end{array}$ \\
\hline Friend or family member & $3.68^{\star \star}$ & $4.03^{\star \star}$ \\
Website of a specific destination & $3.63^{\star \star}$ & $3.99^{\star \star}$ \\
Search for online reviews & $3.60^{\star \star}$ & $3.98^{\star \star}$ \\
Google & $3.56^{\star \star}$ & $3.92^{\star \star}$ \\
Travel guide/travel book & $3.38^{\star \star}$ & $3.61^{\star \star}$ \\
Trip advisor & $3.34^{\star \star}$ & $3.76^{\star \star}$ \\
Travel agent & 3.18 & 3.22 \\
YouTube & 2.84 & 2.98 \\
TV show/TV news story & $2.83^{\star \star}$ & $3.08^{\star \star}$ \\
Facebook & 2.81 & 3.10 \\
Pinterest & $2.71^{\star \star}$ & $3.05^{\star \star}$ \\
Television ad & $2.70^{\star \star}$ & $2.97^{\star \star}$ \\
Instagram & $2.68^{\star}$ & $2.90^{\star}$ \\
Web banner/internet ad & 2.65 & 2.76 \\
An app & $2.55^{\star \star}$ & $2.84^{\star \star}$ \\
Magazine article & 2.47 & 2.93 \\
Snapchat & 2.41 & 2.45 \\
Tumblr & 2.38 & 2.44 \\
Radio ad & $2.37^{\star \star}$ & $2.56^{\star \star}$ \\
Newspaper ad & 2.33 & 2.50 \\
Twitter & $2.33^{\star \star}$ & $2.61^{\star *}$ \\
Magazine ad & 2.25 & 2.59 \\
Notes: ${ }^{\star} p<0.05 ;{ }^{\star \star} p<0.01$ & & \\
& &
\end{tabular}

Previous studies examining millennials have focused on their presumably shared characteristics: millennials are young and carefree, expect instant gratification, seek out unique experiences, etc. However, in order to better examine the motivations and perceived benefits of travel among millennials (as well as the utility of travel mediums); this research was designed to explore the potential differences among millennials with respect to age and income.

From a theoretical standpoint, the findings of this study provide direction for future research. Several extant studies examining travel motivations and travel benefits associated with generations have incorporated age cohort segmentation approaches (Leask et al., 2014; Sarigollu and Huang, 2005). Based on the study findings, generational cohort theories are not wholly successful in determining unique marketing segments. Therefore, additional segmentation approaches should be considered, including criterion-based segmentation strategies and life-cycle segmentation approaches.

Results of this study also provide several practical implications for travel destination marketers. Based solely on the number of responses cited by all millennials regarding primary motivations to travel, destination marketers singularly focused on attracting and maintaining millennial tourists should address hedonic motivations (fun and pleasure) as well as the motivation to visit friends and family. Subsequently, the promotion of destinations as being family/friend centric should be explored, perhaps expanding a destination image to include relationship-centric activities and events, via friend/family reunions, weddings, girlfriend getaways, etc. Further research should also explore what specifically constitutes as "fun and pleasure" for millennial travelers.

Additional findings, however, suggest that millennial subgroups have significantly divergent travel motivations, as the motivational profiles of "YFMs" were starkly different than the motivational profile of "PMs." "YFMs", in comparison to "PMs," were far more motivated to travel in order to engage in exploration, education, novelty, hedonic interests, and visiting friends and family. Most of these stated travel motivations fit the prevailing image of all millennials, as previous studies have largely characterized millennials as adventure seeking and fun loving (Joseph and Wearing, 2014).

Destination marketers should recognize that, among the more frivolous motivations stated, the desire to both learn and to spend time with friends and family exists among "YFMs." The inclusion 
of these additional motivations in the pursuit of "YFMs" can be creatively integrated within the traditional "millennial" profile. For example, travel destinations that are perceived to be "educational" should appeal directly to young and free millennials. However, destinations such as these should also provide education in a way that promotes adventure, fun, and family. As millennials have been found to be tech-savvy (Graen and Grace, 2015, p. 395), destinations that are projected as educational can utilize this notion, incorporating it among the educational activities it provides.

In contrast to "YFMs," "PMs" are far more motivated (in comparison to YFMs) to travel for rest and relaxation, leisure and recreation, and business/status. Therefore, destination marketers should be charged with providing "PMs" millennials with advertising that promotes the promise of rest and the acknowledgment of their status. For example, "PMs" could be "rewarded" with discounts for business travel, or provided with additional amenities (spa treatments or private beach-front cabanas). Future research should further examine the activities and messaging that would best underscore the desire for "PMs" to receive rest, leisure, and status.

Both millennial subgroups rated the following travel benefits in the following order: entertainment, relationships, health, and education. Based on this finding, it would seem practical for destination marketers to devote their focus on impressing upon millennials that their destination can successfully deliver entertainment and increase/improve various aspects of relationships (bonding, networking, etc.). Interestingly, these two perceived benefits of travel are nearly identical to the responses of all millennials regarding the top motivations to travel (hedonic and visiting friends/family). It should also be noted that "PMs" registered significantly higher mean scores for all four primary benefits of travel. Therefore, additional research is needed to explore why "YFMs" find traveling to be less beneficial than "PMs."

Significant differences were also found between the two groups and their perceptions of additional benefits of travel. A larger percentage of "YFMs" cited experience/memory, novelty, happiness, entertainment, none, and relationships as additional benefits to travel. Further, a larger percentage of "PMs" cited relaxation and health. Thus, differentiated marketing strategies for each of the millennial subgroups, implementing effective signage, employee reinforcement, and advertising focused on perpetuating the benefits of travel (as opposed to destination features) could prove advantageous.

However, upon review of the top two responses regarding additional travel benefits (in addition to the four primary benefits) provided by both millennial subgroups, a rather collective view on travel appears. "Relaxation" and "none" represent the top two responses for both millennial groups (accounting for 34.2 percent of "YFMs" and 31.0 percent of "PMs" total responses). Based on this finding, it would seem that educating and promoting the benefits of travel to the millennial generation overall has not been successful. Additional research should focus on how to effectively demonstrate the benefits of travel (beyond relaxation) to all millennials.

Although significant differences existed among the millennial subgroups regarding utility, "YFMs" and "PMs" shared the top four travel mediums: friend or family, website of a specific destination, search for online reviews, and Google. Although word-of-mouth advertising has been a prominent research objective, more research is needed to better understand how to garner positive word-of-mouth advertising from millennials (and millennial subgroups).

Interestingly, the least effective mediums for both groups included radio, newspaper, and magazine advertisements, suggesting that traditional advertising is not as effective in attracting millennials as other travel mediums. In addition, future research should examine effective destination websites' for millennials. For example, Doster (2013) recommended that websites geared toward millennials specifically provide an easy platform for consumers to provide reviews and share experiences, consider providing coupons online, and to voice their opinions. As millennials have been identified as experts and/or influencers among all generations (Torres, 2015), destination marketers must improve websites, enticing millennials to become early adopters.

This study is subject to the following limitations. First, the two millennial subgroups were categorized only via age and annual income. Other variables, including gender, race, and level of 
education could have provided additional insight. Second, the sample of this study was limited to US residents, thereby reducing the potential for cultural and/or regional findings. A third limitation concerns the sample used. Since the panel utilized did not include the entire US results, it does not necessarily represent the whole US millennial population. Although the segmentation of millennials via age and annual income has not been popular to date, the results of this study should guide future segmentation strategies of millennial subgroups and suggest that millennials are not a homogeneous group.

\section{References}

Andersson, B. and Nilsson, S. (1964), "Studies in the reliability and validity of the critical incident technique", Journal of Applied Psychology, Vol. 48 No. 6, pp. 398-403.

Ansolabehere, S. and Schaffner, B.F. (2014), "Does survey mode still matter? Findings from a 2010 multimode comparison", Political Analysis, Vol. 22 No. 3, pp. 285-303.

Baloglu, S. and Uysal, M. (1996), "Market segments of push and pull motivations: a canonical correlation approach", International Journal of Contemporary Hospitality Management, Vol. 8 No. 3, pp. 32-8.

Beauchamp, M.B. and Barnes, D. (2015), "Delighting baby boomers and millennials: factors that matter most”, The Journal of Marketing Theory and Practice, Vol. 23 No. 3, pp. 338-50.

Beh, A. and Bruyere, B.L. (2007), "Segmentation by visitor motivation in three Kenyan national reserves", Tourism Management, Vol. 28 No. 6, pp. 1464-71.

Belch, G. and Belch, M. (2015), Advertising and Promotion: An Integrated Marketing Communications Perspective, 10th ed., McGraw-Hill Education, New York, NY.

Benckendorff, P., Moscardo, G. and Pendergast, D. (2010), Tourism and Generation Y, CABI, Oxfordshire.

Bolton, R.N., Parasuraman, A., Hoefnagels, A., Migchels, N., Kabadayi, S., Gruber, T., Loureiro, Y.K. and Solnet, D. (2013), "Understanding Generation $Y$ and their use of social media: a review and research agenda", Journal of Service Management, Vol. 24 No. 3, pp. 245-67.

Bosnjak, M., Haas, I., Galesic, M., Kaczmirek, L., Bandilla, W. and Couper, M.P. (2013), "Sample composition discrepancies in different stages of a probability-based online panel”, Field Methods, Vol. 25 No. 4, pp. 339-60.

Brida, J.G., Disegna, M. and Scuderi, R. (2013), "Visitors to two types of museums: do expenditure patterns differ?", Tourism Economics, Vol. 19 No. 5, pp. 1027-47.

Butterfield, L.D., Borgen, W.A., Amundson, N.E. and Maglio, A.T. (2005), "Fifty years of the critical incident technique: 1954-2004 and beyond", Qualitative Research, Vol. 5 No. 4, pp. 475-97.

Cha, S., McCleary, K.W. and Uysal, M. (1995), "Travel motivations of Japanese overseas travelers: a factorcluster segmentation approach", Journal of Travel Research, Vol. 34 No. 1, pp. 33-9.

Chandon, P., Wansink, B. and Laurent, G. (2000), "A benefit congruency framework of sales promotion effectiveness", Journal of Marketing, Vol. 64 No. 4, pp. 65-81.

Chen, C.C. and Petrick, J.F. (2013), "Health and wellness benefits of travel experiences: a literature review", Journal of Travel Research, Vol. 52 No. 6, pp. 709-19.

Chen, G., Bao, J. and Huang, S. (2014), "Segmenting Chinese backpackers by travel motivations", International Journal of Tourism Research, Vol. 16 No. 4, pp. 355-67.

Chiang, L., Manthiou, A., Tang, L., Shin, J. and Morrison, A. (2014), "A comparative study of generational preferences for trip-planning resources: a case study of international tourists to Shanghai", Journal of Quality Assurance in Hospitality and Tourism, Vol. 15 No. 1, pp. 78-99.

Chung, J.Y., Chen, C.-C. and Lin, Y.-H. (2015), "Cross-strait tourism and generational cohorts", Journal of Travel Research, Vol. 55 No. 6, pp. 813-26.

Collum, K.K. and Daigle, J.J. (2015), "Combining attitude theory and segmentation analysis to understand travel mode choice at a national park", Journal of Outdoor Recreation and Tourism, Vol. 9 No. 9, pp. 17-25.

Crompton, J.L. (1979), "Motivations for pleasure vacation", Annals of Tourism Research, Vol. 6 No. 4, pp. 408-24. 
Dann, G.M. (1981), "Tourist motivation an appraisal”, Annals of Tourism Research, Vol. 8 No. 2, pp. 187-219.

Doster, L. (2013), "Millennial teens design and redesign themselves in online social networks", Journal of Consumer Behavior, Vol. 12 No. 4, pp. 267-79.

Durko, A.M. and Petrick, J.F. (2013), "Family and relationship benefits of travel experiences: a literature review", Journal of Travel Research, Vol. 52 No. 6, pp. 720-30.

D’Urso, P., Disegna, M., Massari, R. and Osi, L. (2016), "Fuzzy segmentation of postmodern touirsts", Tourism Management, Vol. 55, pp. 297-308.

Fromm, J. and Garton, C. (2013), Marketing to Millennials: Reach the Largest and Most Influential Generation of Consumers Ever, AMACOM, New York, NY.

Fromm, J., Butler, J. and Dickey, C. (2015), "How to engage millennials: reimagining the consumer as a partner, not a target audience, to increase engagement”, Journal of Brand Strategy, Vol. 4 No. 1, pp. 27-36.

Gardiner, S., King, C. and Grace, D. (2012), "Travel decision making: an empirical examination of generational values, attitudes, and intentions", Journal of Travel Research, Vol. 52 No. 3, pp. 310-24.

Garikapati, V.M., Pendyala, R.M., Morris, E.A., Mokhtrarian, P.L. and McDonald, N. (2016), "Activity patterns, time use, and travel of Millennials: a generation in transition?", Transport Reviews, Vol. 36 No. 5, pp. 558-84.

Graen, G. and Grace, M. (2015), "Positive industrial and organizational psychology: designing for tech-savvy, optimistic, and purposeful millennial professionals' company cultures”, Industrial and Organizational Psychology, Vol. 8 No. 3, pp. 395-408.

Gurtner, S. and Soyez, K. (2016), "How to catch the generation Y: identifying consumers of ecological innovations among youngsters", Technological Forecasting and Social Change, Vol. 106, pp. 101-07.

Hritz, N.M., Sidman, C.J. and D'Abundo, M. (2014), "Segmenting the college educated generation Y health and wellness traveler", Journal of Travel and Tourism Marketing, Vol. 31 No. 1, pp. 132-45.

Hsu, C.H. and Kang, S.K. (2009), "Chinese urban mature travelers' motivation and constraints by decision autonomy", Journal of Travel \& Tourism Marketing, Vol. 26 No. 7, pp. 703-21.

Hung, K. and Petrick, J. (2012), "Testing the effects of congruity, travel constraints, and self-efficacy on travel intentions: an alternative decision-making model”, Tourism Management, Vol. 33 No. 4, pp. 855-67.

Iso-Ahola, S.E. (1982), "Toward a social psychological theory of tourism motivation: a rejoinder", Annals of Tourism Research, Vol. 12 No. 1, pp. 256-62.

Joseph, J. and Wearing, S.L. (2014), "Does bear do it for you? Gen-Y gappers and alternative tourism", Annals of Leisure Research, Vol. 17 No. 3, pp. 314-39.

Kim, H., Xiang, Z. and Fesenmaier, D.R. (2015), "Use of the internet for trip planning: a generational analysis", Journal of Travel \& Tourism Marketing, Vol. 32 No. 3, pp. 276-89.

Leask, A., Fyall, A. and Barron, P. (2014), "Generation Y: an agenda for future visitor attraction research", International Journal of Tourism Research, Vol. 16 No. 5, pp. 462-4.

Lehto, X.Y., Jang, S.C., Achana, F.T. and O'Leary, J.T. (2008), "Exploring tourism experience sought: a cohort comparison of baby boomers and the silent generation", Journal of Vacation Marketing, Vol. 14 No. 3 , pp. 237-52, doi: 10.1177/1356766708090585.

Li, R., Meng, F., Uysal, M. and Mihalik, B. (2013), “Understanding China's long-haul outbound travel market: an overlapped segmentation approach", Journal of Business Research, Vol. 66 No. 6, pp. 786-93.

Loda, M.D., Coleman, B.C. and Backman, K.F. (2010), “Walking in memphis: testing one DMO's marketing strategy to millennials", Journal of Travel Research, Vol. 49 No. 1, pp. 46-55.

Lu, C.-C., Hsu, Y.-L., Lu, Y.-I. and Lin, W.-J. (2015), "Measuring tourist satisfaction by motivation, travel behavior and shopping behavior: the case of lake scenic area in Taiwan", International Journal of Organizational Innovation, Vol. 8 No. 1, pp. 117-32.

Mayo, E.J. and Jarvis, L.P. (1981), The Psychology of Leisure Travel: Effective Marketing and Selling of Travel Services, CBI Publishing Company Inc, Boston, MA.

Muralidharan, S., Rejon-Guardia, F. and Xue, F. (2016), "Understanding the green buying behavior of younger millennials from India and the United States: a structural equation modeling approach", Journal of International Consumer Marketing, Vol. 28 No. 1, pp. 54-72. 
Namkung, Y. and Jang, S. (2009), "The effects of interactional fairness on satisfaction and behavioral intentions: mature versus non-mature customers", International Journal of Hospitality Management, Vol. 28 No. 3, pp. 397-405.

Patterson, I., Sie, L., Balderas-Cejuda, A. and Rivera-Hernaez, O. (2017), "Changing trends in the baby boomer travel market: important of memorable experiences", Journal of Hospitality Marketing \& Management, Vol. 26 No. 4, pp. 347-60.

Patterson, I.R. and Pan, R. (2007), "The motivations of baby boomers to participate in adventure tourism and the implications for adventure tourism providers", Annals of Leisure Research, Vol. 10 No. 1, pp. 26-53.

Pendergast, D. (2009), "Generational theory and home economics: future proofing the profession", Family \& Consumer Sciences Research Journal, Vol. 37 No. 4, pp. 504-22.

Pennington-Gray, L., Fridgen, J. and Stynes, D. (2003), "Cohort segmentation: an application to tourism", Leisure Sciences, Vol. 25 No. 4, pp. 341-61.

Petrick, J.F. and Huether, D. (2013), "Is travel better than chocolate and wine? The benefits of travel, a special series”, Journal of Travel Research, Vol. 52 No. 6, pp. 705-08.

Polzin, S.E., Chu, X. and Godfrey, J. (2014), "The impact of millennials' travel behavior on future personal vehicle travel”, Energy Strategy Reviews, Vol. 5, pp. 59-65.

Santos, M.C., Veiga, C. and Aguas, P. (2016), "Tourism services: facing the challenge of new tourist profiles", Worldwide Hospitality and Tourism Themes, Vol. 8 No. 6, pp. 654-69.

Sarigollu, E. and Huang, R. (2005), "Benefits segmentation of visitors to Latin America", Journal of Travel Research, Vol. 43 No. 3, pp. 277-93.

Shoemaker, S. (1994), "Segmenting the US travel market according to benefits realized", Journal of Travel Research, Vol. 32 No. 3, pp. 8-21.

Stone, M.J. and Petrick, J.F. (2013), "The educational benefits of travel experiences: a literature review", Journal of Travel Research, Vol. 52 No. 6, pp. 731-44.

Swanson, S.R. and Hsu, M.K. (2009), "Critical incidents in tourism: failure, recovery, customer switching, and word-of-mouth behaviors", Journal of Travel \& Tourism Marketing, Vol. 26 No. 2, pp. 180-94.

Torres, E.N. (2015), "The influence of others on the vacation experience: an ethnographic study of psychographics, decision making, and group dynamics among young travelers", Journal of Hospitality Marketing \& Management, Vol. 24 No. 8, pp. 826-56.

Viswanatham, V.J. (2013), "A dual-system approach to understanding 'generation Y' decision making”, Journal of Consumer Marketing, Vol. 30 No. 6, pp. 484-92.

Yousefi, M. and Marzuki, A. (2015), "An analysis of push and pull motivational factors of international tourists to Penang, Malaysia", International Journal of Hospitality \& Tourism Administration, Vol. 16 No. 1, pp. 40-56.

Zeng, B. and Gerritsen, R. (2014), "What do we know about social media in tourism? A review", Tourism Management Perspectives, Vol. 10, pp. 27-36.

\section{Further reading}

Almeida, A., Correia, A. and Pimpao, A. (2014), "Segmentation by benefits sought: the case of rural tourism in Madiera”, Current Issues in Tourism, Vol. 17 No. 9, pp. 813-31.

Beerli, A. and Martin, J.D. (2004), "Factors influencing destination image", Annals of Tourism Research, Vol. 31 No. 3, pp. 657-81.

Chen, C.C., Petrick, J.F. and Shahvali, M. (2016), "Tourism experiences as a stress reliever: examining the effects of tourism recovery experiences on life satisfaction”, Journal of Travel Research, Vol. 55 No. 2, pp. 150-60.

Chiu, L.K., Dzakiria, H., Kasim, A. and Scarlat, C. (2013), "The need to understand cultural heritage tourists behavior", Advances in Business-Related Scientific Research, Vol. 4 No. 1, pp. 85-97.

Crompton, J.L. and McKay, S.L. (1997), "Motives of visitors attending festival events", Annals of Tourism Research, Vol. 24 No. 2, pp. 425-39.

Dolnicar, S., Yanamandram, V. and Cliff, K. (2012), "The contribution of vacations to quality of life", Annals of Tourism Research, Vol. 39 No. 1, pp. 59-83. 
Fry, R. (2016), "Millennials overtake baby boomers as America's largest generation", available at: www.pewresear ch.org/fact-tank/2016/04/25/Millennials-overtake-babyboomers/ (accessed February 9, 2017).

Gardiner, S., Grace, D. and King, C. (2014), "The generation effect: the future of domestic tourism in Australia", Journal of Travel Research, Vol. 53 No. 6, pp. 705-20.

Grimm, K.E. and Needham, M.D. (2012), "Moving beyond the 'l' in motivation: attributes and perceptions of conservation volunteer tourists", Journal of Travel Research, Vol. 51 No. 4, pp. 488-501.

Huang, S. and Hsu, C. (2005), "Mainland Chinese residents' perceptions and motivations of visiting Hong Kong: evidence from focus group interviews", Asia Pacific Journal of Tourism Research, Vol. 10 No. 2, pp. 191-205.

Huang, Y.C. and Petrick, J.F. (2010), "Generation Y's travel behaviors: a comparison with baby boomers and generation X", in Beckendork, P., Moscardo, G. and Pendergast, D. (Eds), Tourism and Generation Y, CABI, Oxford, pp. 27-37.

Iverson, N.M., Hem, L.E. and Mehmetoglu, M. (2016), "Lifestyle segmentation of tourists seeking naturebased experiences: the role of cultural values and travel motives", Journal of Travel \& Tourism Marketing, Vol. 33 No. S1, pp. 3338-66.

Jang, S and Ham, S. (2009), "A double-hurdle analysis of travel expenditure: baby boomer seniors versus older seniors", Tourism Management, Vol. 30 No. 3, pp. 372-80.

Kim, W.-G., Park, Y., Gazzoli, G. and Sheng, E. (2011), "Benefit segmentation of international travelers to Macau, China”, Journal of Quality Assurance in Hospitality \& Tourism, Vol. 12 No. 1, pp. 28-57.

Kotler, P. (1993), Marketing Management, Prentice Hall, New York, NY.

Liu, C. and Chou, S. (2016), "Tourism strategy development and facilitation of integrative processes among brand equity, marketing and motivation”, Tourism Management, Vol. 54, pp. 298-308.

McCormick, K. (2016), "Celebrity endorsements: influence of a product-endorser match on Millennials attitudes and purchase intentions", Journal of Retailing and Consumer Services, Vol. 32, pp. 39-45.

Neal, J.D., Uysal, M. and Sirgy, M.J. (2007), "The effect of tourism services on travelers' quality of life”, Journal of Travel Research, Vol. 46 No. 2, pp. 154-63.

Park, D.-B. and Yoon, Y.-S. (2009), "Segmentation by motivation in rural tourism: a Korean case study", Tourism Management, Vol. 30 No. 1, pp. 99-108.

Philip, B. (2016), "A tale of two millennials", Canadian Business, Vol. 89 No. 13, pp. 23-35.

Poria, Y., Reichel, A. and Biran, A. (2006), "Heritage site management: motivations and expectations", Annals of Tourism Research, Vol. 33 No. 1, pp. 162-78.

Sung, Y.-K., Chang, K.-C. and Sung, Y.-E. (2016), "Market segmentation of international tourists based on motivation to travel: a case study of Taiwan", Asia Pacific Journal of Tourism Research, Vol. 21 No. 8, pp. 862-82.

\section{Corresponding author}

Steven J. Migacz can be contacted at: sm1708@tamu.edu

For instructions on how to order reprints of this article, please visit our website: 